\title{
Vissza a jövőbe: gastro-oesophagealis junctio subepitheliális tumorának laparoszkópos transgastricus resectiója
}

\section{Back to the future: laparoscopic transgastric resection of a subepithelial tumor in the gastroesophageal junction}

\author{
VARGA ZSOLT ${ }^{1,2}$, SÁRKÁNY PÉTER ${ }^{3}$, TÓTH DEZSÖ1,2,@ \\ ${ }^{1}$ Debreceni Egyetem Klinikai Központ, Sebészeti Klinika (igazgató: dr. Tóth Dezső) \\ ${ }^{2}$ Borsod-Abaúj Zemplén Megyei Központi Kórház és Egyetemi Oktatókórház, Sebészeti Osztály \\ (mb. osztályvezető főorvos: dr. Botos Ákos) \\ ${ }^{3}$ Borsod-Abaúj Zemplén Megyei Központi Kórház és Egyetemi Oktatókórház, \\ Központi Aneszteziológiai és Intenzív Terápiás Osztály (osztályvezető főorvos: dr. Sárkány Péter)
}

\begin{abstract}
Esetismertetés: A gyomor subepitheliális tumorainak laparoszkópos ékresectiója egy széleskörűen elfogadott és alkalmazott eljárás. A gastro-oesophagealis junctio (GOJ) közeli elváltozások esetén ez a technika azonban a gyomorbemenet szükületének magas kockázata miatt erősen korlátozott. Ilyen lokalizáció esetén megfelelő technika lehet a laparoszkópos transgastricus resectio. Esetünkben egy 44 éves férfi dysphagiájának hátterében azonosított subepitheliális tumor resectióját végeztük el ilyen módon. A mütét során a pneumoperitoneum készítését követően a gyomrot orogastricus szonda segítségével insuffláltuk, majd 3 darab ballonnal rendelkező portot vezettünk a gyomorba. A $6 \times 3 \times 3 \mathrm{~cm}$-es elváltozás intragastricus kimetszését követően a nyálkahártyát tovafutó öltéssorral zártuk. A speciment zsákba helyeztük, majd a gyomorból és a hasüregből eltávolítottuk. A portok gastrotomiás nyílásait zártuk. 24 órán át nasogastricus szondát hagytunk hátra, hasüri draint nem hagytunk vissza. A pneumoperitoneum idő 115 perc volt, vérveszteséget vagy intraoperatív szövődményt nem észleltünk. Eseménytelen posztoperatív szak után a beteget a mütétet követő harmadik napon otthonába bocsátottuk. A szövettani vizsgálat leiomyomát igazolt. Megbeszélés: Bár a páciens utánkövetése még folyamatban van, az irodalmi adatok alapán GOJ közeli elváltozások esetén a transgastricus technika biztonságos, hatékony, valamint jó funkcionális eredményt biztosító eljárás, a kiújulás magasabb kockázata nélkül.
\end{abstract}

Kulcsszavak: gyomor, sebészet, laparoszkópia, transgastricus

Case report: Laparoscopic wedge resection of the subepithelial tumors of the stomach is a widely accepted and utilized approach. The use of this technique for lesions located near the gastroesophageal junction (GEJ) is rather limited by the high risk of consequential stenosis of the gastric inlet. The laparoscopic transgastric resection can be a feasible choice for this location. A 44-year-old male patient had been investigated for dysphagia, which confirmed a subepithelial gastric lesion. We performed the resection of the tumor using this technique. After the creation of pneumoperitoneum, the stomach was insufflated using an orogastric tube, then 3 balloon-type ports were inserted intragastrically. The $6 \times 3 \times 3 \mathrm{~cm}$ large tumor was resected and the mucosa was closed by running sutures. The specimen was placed into a plastic bag, then retrieved from the stomach and the abdominal cavity. The gastrotomy sites of the ports on the stomach were closed. A nasogastric tube was left in situ for 24-hours without any intraabdominal drains. The pneumoperitoneum time was 115 minutes long, blood loss or intraoperative complication was not noticed. The postoperative period was uneventful, and the patient was discharged from the hospital three days after surgery. The histological examination confirmed the diagnosis of leiomyoma. Summary: Even though the follow-up of the patient is ongoing, according to the scientific literature, transgastric resection of subepithelial tumors located near the GEJ is a safe and effective technique, which provides good functional results, without having a higher risk for recurrence.

Keywords: gastric, surgery, laparoscopy, transgastric

Beérkezett: 2021. március 22.; elfogadva: 2021. április 20.

\footnotetext{
@Levelezési cím/Corr. address: Dr. Tóth Dezső, Tel.: +36 52255 544, Fax: +36 52255 544, 55949 , E-mail: dr.toth.dezso@med.unideb.hu
} 


\section{Bevezetés}

A gyomor subepitheliális tumorainak differeciáldiagnosztikája meglehetősen sokrétü: a benignus leiomyomáktól és schwannomáktól a gastrointestinalis stromális tumorokon (GIST) át a különböző sarcomákig tart. A legnagyobb arányt $(78 \%)$ a különböző jóindulatú elváltozások teszik ki. ${ }^{1}$ Mivel az ilyen tumorokat leggyakrabban normál mucosa fedi, a pontos diagnózis megállapítása még gastroscopia, endoszkópos ultrahang, metszet képalkotók segítéségével is nehézkes. $2 \mathrm{~cm}$-nél nagyobb elváltozások esetén az endoszkópos ultrahangvizsgálat által vezérelt finomtü biopszia (EUS-FNA) segítheti a diagnózist, azonban ennek pontossága submucosus tumoroknál $60 \%$ körül van. ${ }^{2}$ Mivel a kivizsgálás során a definitív diagnózis felállítása limitált, klinikai panaszt okozó elváltozásoknál a sebészi vagy endoszkópos kimetszés még mindig az elsődleges kezelési mód. A 2017-es ESGE (European Society of Gastrointestinal Endoscopy) ajánlás panaszt okozó elváltozás esetén a biopsziával szemben foglal állást, mivel az nagy valószínüséggel nem befolyásolja a beteg ellátását, ellenben magában hordozza a szövődmény lehetőségét. ${ }^{2}$ A standard mütéti technika az érintett terület laparoszkópos extragastricus ék-resectiója linear staplerek segítségével, mely biztosítja a minimális invazív mütétek minden előnyét, valamint a megfelelő onkológiai és funkcionális eredményeket. Azonban ezt a technikát választva a GOJ és pylorus közeli elváltozások esetén a gyomor be-, illetve kimenetének deformitása és a következményes szükülete súlyos következményekkel járhat.

A transgastricus (intragastricus) laparoscopos mütétek koncepcióját 1995-ben Osahi írta le ${ }^{3}$ korai gyomorrákok és leiomyomák esetén. Ezt tekintik a gyomorrák minimálisan invazív ellátásának első lépésének. A subepitheliális gyomortumorok laparoszkópos transgastricus resectiójának technikáját először Geis és munkatársai publikálták 1996-ban. ${ }^{4}$ Azóta számos közlemény bizonyította ezen technika biztonságos voltát és kivitelezhe- tőségét GOJ közeli elváltozások esetén. ${ }^{5}$ A legtöbb esetben az elváltozás resectiója linear stapler segítségével történt. Ez azonban nagyobb méretű vagy széles alapú tumorok esetén a már említett szükületek elkerülése érdekében komoly technikai akadályokba ütközhet. Jól ismert ilyen esetekben a gyomorbemenet deformitásának és szükületek kialakulásának a lehetősége. ${ }^{6}$ Alternatív megoldásként ismert a GOJ-közeli benignus elváltozások miatt végzett proximális gyomorresectio ${ }^{7}$ - azonban nem szabad elfelejtenünk az ilyen beavatkozások jelentősen magasabb morbiditását és mortalitását, illetve a hoszszú távon kialakuló GORB (gastro-oesophagealis reflux betegség) lehetőségét. A teljes vagy proximális gyomorresectiók elkerülése érdekében nagyobb méretü GOJ-közeli subepitheliális elváltozások esetén egyénre szabott beavatkozás szükséges.

\section{Anyag és módszerek}

A 44 éves jó általános állapotú beteg kórelőzményében jelentősebb betegség vagy beavatkozás nem szerepel. A mütét előtt 3 hónappal indult kivizsgálása fokozódó dysphagia miatt. Az elvégzett gastroscopia során a GOJ vonalában a hátsó falon a kisgörbület területén egy kb. 4 cm-es méretü lumenbe domborodó, azt szükítő, ép nyálkahártyával fedett elváltozás került leírásra (1. ábra). A vizsgálat egyéb eltérést nem igazolt. Has és mellkas CT-vizsgálata során a cardiának megfelelően egy kb. $36 \times 35 \times 30$ mm-es lumenbe domborodó lágyrész képlet ábrázolódott, mely a gyomor falától nem volt elhatárolható, a képlet érdemi kontrasztanyag halmozást nem mutatott (2. ábra). Egyéb organikus mell- vagy hasüri eltérés nem igazolódott. Az elváltozás pontosabb karakterizálását endoszkópos ultrahang-vizsgálattal terveztük, azonban a COVID-19 okozta járványügyi helyzetben ez csak más intézményben lett volna bizonytalan előjegyzéssel kivitelezhető. Differenciáldiagnosztikai szempontból mesenchymális benignoma és GIST
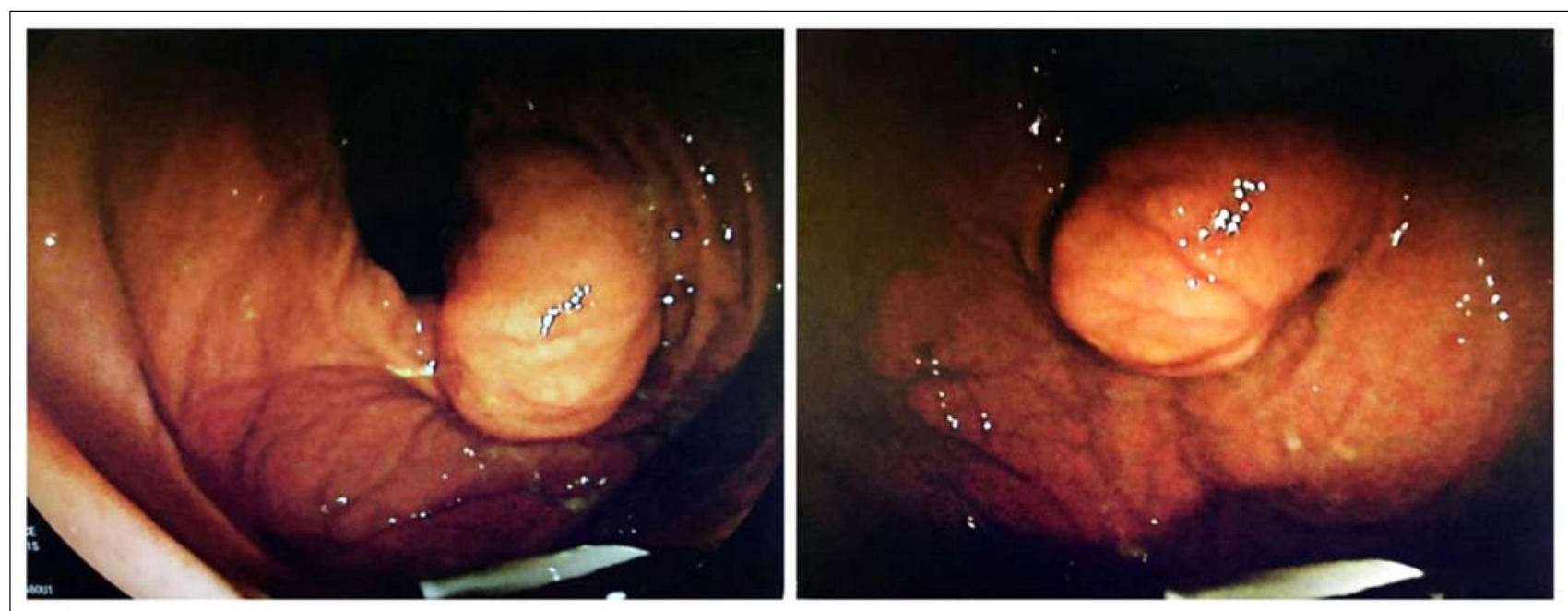

1. ábra. Gastroscopia során a GOJ vonalában a hátsó falon a kisgörbület területén egy kb. 4 cm-es méretű lumenbe domborodó, azt szükítő, ép nyálkahártyával fedett elváltozás látható 


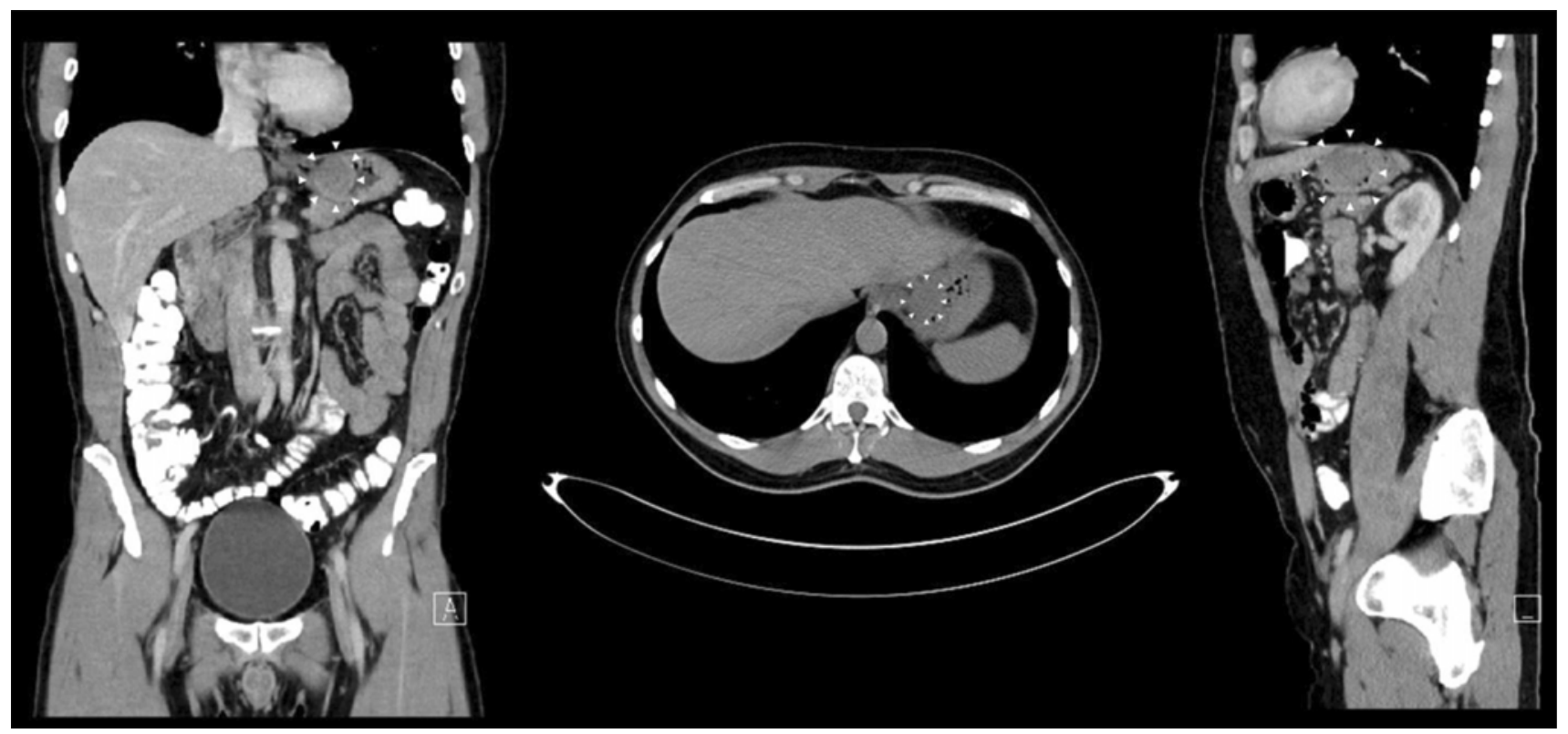

2. ábra. Mellkas-has-kismedencei CT-vizsgálat során a cardiának megfelelően egy kb. $36 \times 35 \times 30$ mm-es lumenbe domborodó lágyrész képlet látható (fehér nyilakkal jelölve), mely a gyomor falától nem elhatárolható, érdemi kontrasztanyag halmozást nem mutat

lehetősége merült fel. Figyelembe véve a CT-vizsgálat által felvetett benignus morfológiát, az elváltozás méretét és a klinikai panaszokat, a mütét elvégzése mellett döntöttünk, annak elhelyezkedése miatt laparoszkópos transgastricus technikával. A mütét előtti kivizsgálás és állapotfelmérés során a beteg ASA I. osztályba volt besorolható, BMI-je
$23,5 \mathrm{~kg} / \mathrm{m}^{2}$ volt. A hatályos intézeti COVID-kérdőív kiértékelése alapján a fertőzés lehetősége alacsony volt, további tesztelést nem tartottak indokoltnak.

A mütétet 12 órával megelőzően $40 \mathrm{mg}$ enoxaparin-nátrium, valamint 30 perccel megelőzően $2 \mathrm{~g}$ cefazolin prophylaxist alkalmaztunk. Felső tápcsatornai ERAS-pro-
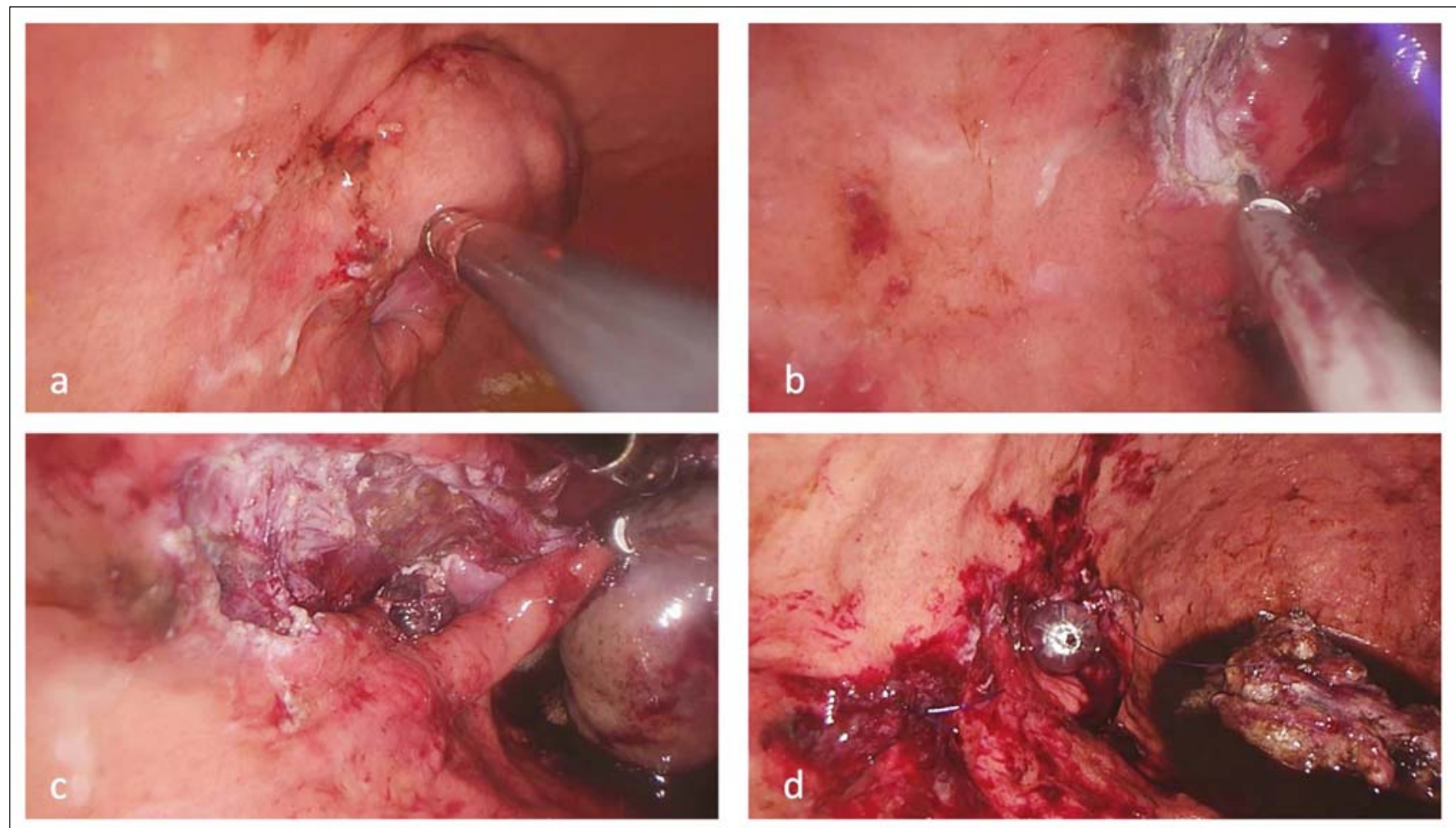

3. ábra. $a$ : a kisgörbület mentén elhelyezkedő, a lumenbe bedomborodó, azt jelentősen szűkítő, ép nyálkahártyával fedett tumor; $b$ : az elváltozás körül a mucosa behasítása ultrahangos dissector segítéségével; $c$ : az elváltozás fölötti nyálkahártya atraumatikus fogóval történő megragadása és a tunica muscularis rétegben elhelyezkedő elváltozás resectiója; $d$ : a nyálkahártya-defektus $3 / 0$ monofil felszívódó tovafutó varratsorral történt egyesítését követő állapot 
tokoll szerint készítettük elő a beteget. A mütétet megelőző este könnyü vacsorát fogyasztott, a mütét elött 3 órával $50 \mathrm{~g}$ maltodextrózt tartalmazó $200 \mathrm{ml}$ szénhidrátoldatot ivott. A mütét reggelén antiszeptikus szappannal végzett zuhany történt a szőrzet eltávolítása nélkül.

A beteget a hátán, „francia” pozícióban fektettük a mütőasztalra. Az operatőr a beteg lábai között, a kamerát kezelő asszisztense a beteg balján, míg a mütős szakasszisztens a beteg jobbján helyezkedett el. Intratrachealis intubáció és narkózis mellett Veress-tü segítségével 13 Hgmm-es pneumoperitoneumot képeztünk, majd bevezettük a $10 \mathrm{~mm}$-es ballonnal ellátott supraumbilicalis portot (Kii First Entry Access System, Applied Medical, USA). Ezen keresztül $30^{\circ}$-os optikát használva szemellenörzés mellett került helyezésre a szintén ballonnal rendelkező $10 \mathrm{~mm}$-es bal oldali epigastrialis, illetve $5 \mathrm{~mm}$-es jobb oldali epigastrialis, valamint $5 \mathrm{~mm}$-es, ballonnal nem rendelkező jobb oldali paraumbilicalis segédport. A gyomorba $32 \mathrm{Ch}$ méretű orogastricus szondát vezetve abból minimális mennyiségü tiszta bennéket evakuáltunk.

Első lépésként diagnosztikus exploráció során a hasüreget áttekintettük esetleges peritonealis vagy máj dissemináció irányában, ezekre utaló eltérést nem észleltünk.

Ezt követően orogastricus szonda segítségével a gyomrot insuffláltuk. Intraoperatív gastroscopia elvégzéséhez gastroenterológus készenlétben állt, azonban az elváltozás elhelyezkedése miatt ennek elsődleges alkalmazása nem tünt szükségesnek. A gyomor elülső falának serosáját ultrahangos dissector segítségével (Ultracision Harmonic Scalpel, Ethicon, Cincinnati, OH, USA) behasítva trokár segítségével vezettük be a gyomor lumenébe a ballonnal rendelkező portokat, a ballonokat insuffláltuk. Az orogastricus szondát a nyelőcsőbe visszahúzva a gastrooesophagealis átmenetben, a kisgörbület mentén azonosítottuk a lumenbe bedomborodó, azt jelentősen szükítő, ép nyálkahártyával fedett tumort ( $3 a$ ábra). A nagy méretü elváltozás körül a mucosát az ultrahangos dissector segítségével átvágva ( $3 b$ ábra) és az elváltozás fölötti nyál- kahártyát atraumatikus fogóval megragadva resecáltuk a tunica muscularis rétegben elhelyezkedő $6 \times 3 \times 3 \mathrm{~cm}$-es elváltozást ( $3 c$ ábra).

A nyálkahártya-defektust 3/0 monofil felszívódó tovafutó varratsorral egyesítettük, vérzést nem észleltünk (3/d ábra). Az orogastricus szondát optikus ellenőrzés mellett $14 \mathrm{Ch}$ méretü nasogastricus szondára cseréltük. Az elváltozás mérete miatt a transoesophagealis eltávolítás nem lett volna biztonságos, ezért transabdominalis extractio mellett döntöttünk. A bal oldali porton keresztül annak gastrotomiás nyílását megnagyobbítva emeltük ki a gyomor lumenéből a speciment, amelyet Endobagbe helyeztünk. Komplett hemostasist követően a gyomor elülső falán ejtett nyílásokat egyrétegü $2 / 0$ monofil tovafutó felszívódó öltéssorral zártuk. A bal oldali portnak megfelelöen a hasfali defektust megnagyobbítva távolítottuk el a speciment tartalmazó zsákot, majd a hasfalat csomós 0 Vicryl-öltésekkel egyesítettük. A speciment megvizsgálva a resectiós szélek makroszkóposan épnek bizonyultak (4. ábra). A hasüregbe visszatekintve a gyomor elülső falát fiziológiás sóoldattal lemosva és a felhasi régiót átöblítve revízió során vérzést vagy melléksérülést nem észleltünk. Hasüri drain hátrahagyása nélkül desuffláltuk a hasüreget. A teljes pneumoperitoneum idő 115 perc volt, vérveszteséget vagy intraoperatív szövődményt nem észleltünk. A portok helyét összesen $10 \mathrm{ml} 5 \mathrm{mg} / \mathrm{ml}$ bupivacain oldattal infiltráltuk (Marcain, Recipharm Monts, Franciaország).

A beteget a mütétet követően 24 órán át éhgyomorra tartottuk. Vitális paraméterei mindvégig normál tartományban voltak, a nasogastricus szonda minimális éhgyomri succust vezetett. A mütétet követő 6 órával folytattuk a megkezdett LMWH prophylaxist, intravénásan $40 \mathrm{mg}$ pantoprazolt alkalmaztunk, melyet másnap per os adagolásra cseréltünk. A mütétet követő 1 . napon a beteg folyadékot fogyaszthatott, nasogastricus szondáját eltávolítottuk. Ezt követően étrendjét fokozatosan bővítettük. A mütétet követő 2. napon eseménytelen posztoperatív szakot követően láztalan, panaszmentes állapotban bocsátottuk otthonába.
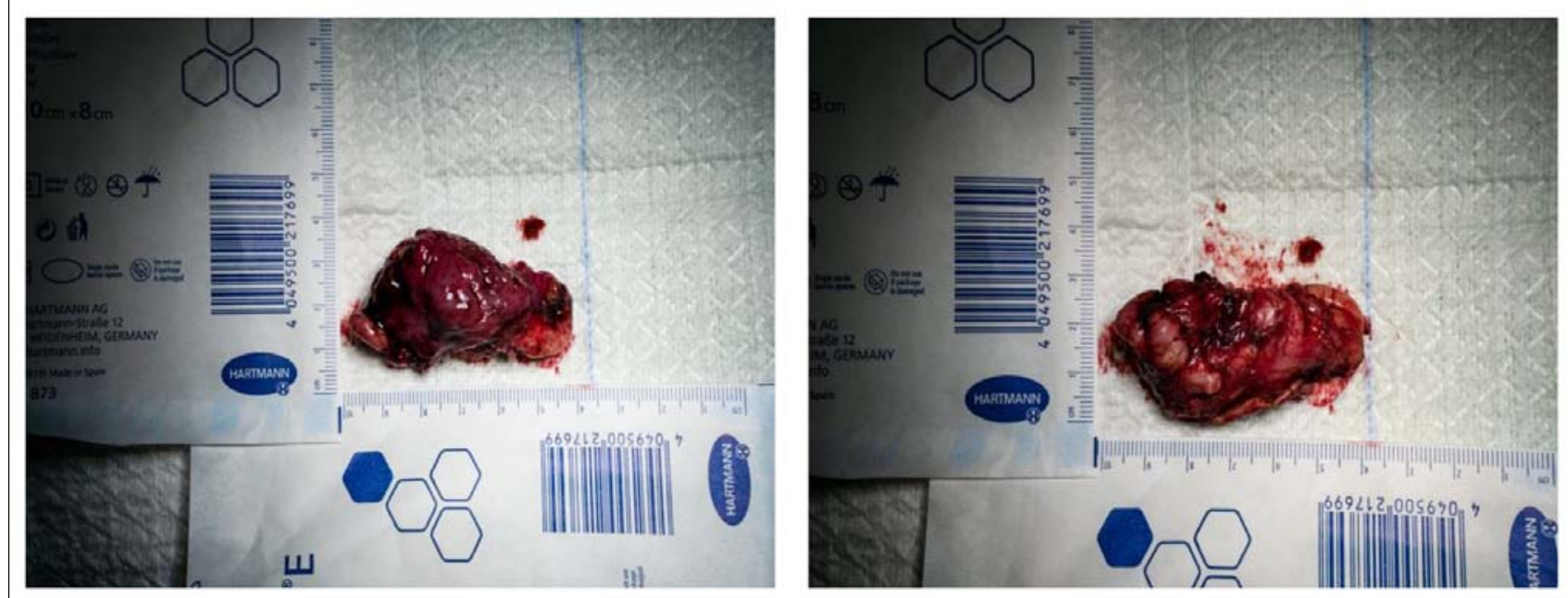

4. ábra. Az eltávolított specimen. Mind a mucosalis, mind az intramuralis oldalon makroszkóposan ép resectiós szélek láthatóak 


\section{Eredmények}

A mütétet követő 3 . nap estéjén a betegnek heveny felső légúti tünetei és láza jelentkezett, ezt követően közepes mennyiségü véres hányást észlelt, mely miatt a lakhelyéhez legközelebbi sürgősségi osztályon jelentkezett. Itt a felvételkor elvégzett rutin SARS-CoV-2 antigén gyorsteszt pozitív eredményt adott.

Stabil vitális paraméterekkel előzetes egyeztetést követően osztályunkra átvettük. Obszervációja során lázas állapotot észleltünk (max. $38,2{ }^{\circ} \mathrm{C}$ testhö), amely miatt a hatályos protokoll szerinti óvintézkedéseket megtettük, vérzéses anamnézisére tekintettel őrző kórteremben izoláltuk. Sürgős mellkas-has-kismedence CT-vizsgálat történt, mely kevés pleuralis folyadékot, elváltozás nélküli tüdőképet és posztoperatív állapotnak megfelelő hasi státust véleményezett. A beteg hemoglobinszintje $91 \mathrm{~g} / 1$ volt, kontroll során csökkenést nem észleltünk, osztályunkon haematemesise nem ismétlödött, a nasogastricus szonda tiszta gyomortartalmat vezetett. Gastroenterológiai konzultáció során gastroscopos vizsgálat szükségessége ismételt vérzés jelentkezése esetén merült fel. Az érvényben lévő intézeti eljárásrendnek megfelelően rendezett haemodinamikai státusszal Infektológiai Osztályra helyeztük át. Itt másnap egy alkalommal melaenás széklet jelentkezett, mely ezt követően már nem ismétlödött, haematemezist nem észleltek, a nasogastricus szondát eltávolították. Vitális paraméterei normál tartományban voltak, kontroll laborvizsgálatok során haemostatusa érdemi változást nem mutatott. Felső légúti panaszai és subfebrilis állapota perzisztáltak, ezek fekvőbeteg ellátást nem indokoltak, így a felvételét követő harmadik napon otthonába bocsátották. Ezt követően további panaszai nem jelentkeztek, a lábadozás eseménytelenül zajlott.

Az eltávolított anyag szövettani vizsgálata submucosus leiomyomát igazolt necrosis, osztódás vagy számottevő magpolymorphia nélkül. Az elváltozás kimetszése az épben történt. Sebészeti kontroll során sebei per primam gyógyultak, dysphagiája megszünt, a per os pantoprazol elhagyását követően sem jelentkeztek refluxos panaszai. Kontroll gastroscopia elvégzését fél év múlva vagy panaszok esetén tartjuk indokoltnak.

\section{Megbeszélés}

Esetbemutatásunk rámutat az általunk választott beavatkozás előnyeire (a minimál invazivitás minden pozitívumával) és technikai igényeire. A gyomor mesenchymális elváltozásainak kezelése során a cél azok épben történő eltávolítása, elhelyezkedésük függvényében egyénre szabott módon. Mivel az ilyen laesiókat ép nyálkahártya fedi, a preoperatív diagnosztika sokszor problémás. A standard „bite-on-bite” biopszia segíthet tisztázni a diagnózist (bár 8 vizsgálat alapján a poolozott diagnosztikai értéke $62 \% ; 17 \%-94 \%$ tartományban). Ha a klinikai panaszok miatt egyébként is mütétet tervezünk, ennek elvégzése nem javasolt. ${ }^{2}$
Az első sikeres laparoszkópos gyomormütétek óta annak létjogosultsága széles körben elfogadottá vált a gyomor subepitheliális elváltozásainak kezelésében, köszönhetően a nyitott mütéthez képest nyilvánvaló elönyöknek (melybe beletartozik a bélmüködés gyorsabb visszatérése, rövidebb kórházi tartózkodás, alacsonyabb posztoperatív fájdalom, munkába való gyorsabb visszatérés stb.). ${ }^{8}$ A mai napig számos különböző laparoszkópos technika került ismertetésre. A legnépszerübb és leggyakrabban választott a stapler segítségével végzett extragastricus ék-resectio. Ez különösen jól használható a nagygörbület mentén az elülső falon, extraluminalis növekedés esetén. Bár egyértelmü előnye a technikai egyszerüség mellett az intraperitonealis kontamináció és dissemináció alacsony valószínüsége, a GOJ-közeli intraluminalis elváltozások esetén a stenosis magas kockázata miatt nem ajánlott. Néhány munkacsoport jó eredményekről számolt be GOJ-közeli elváltozásoknál végzett laparoszkópos gastrectomiákról és proximalis gyomorresectiókról. ${ }^{9}$ Figyelembe véve, hogy ezeknek az elváltozásoknak a 80\%-a benignus, egy hasonló kockázatú beavatkozás elvégzése erősen szelektált esetekben javasolható. ${ }^{10}$

Ilyen esetekben Tagaya ballonnal ellátott portok, valamint stapler segítségével végzett intragastricus resectiót javasolta 6 eset alapján. ${ }^{5}$ Nagyobb méretü $(>4 \mathrm{~cm})$ tumorok esetén azonban sem az általuk alkalmazott transoesophagealis extractio, sem a stapler alkalmazása nem kivitelezhető biztonsággal. Ennek megfelelően módosítottuk a mütéti technikánkat.

Maga a laparoszkópos transgastricus resectio a hátsó falon, intraluminalisan elhelyezkedő tumorok esetén javasolt. Ilyen módon közvetlenül látható az elváltozás és ellenőrizhető a resectiós szél. Xu és munkatársai 12 eset retrospektív vizsgálatával erôsítették meg a technika biztonságos és hatékony voltát. ${ }^{11}$ Mind a manuálisan, mind a stapler segítségével végzett resectio elfogadott, előbbinek előnye a kevesebb eltávolított ép szövet, a lumen szükületének alacsonyabb elméleti kockázata mellett. ${ }^{12}$ Erre vonatkozóan prospektív összehasonlító vizsgálatok nem történtek.

A gyomortartalom hasüri kontaminációja érdekében a gyomor komplett kiürítése és a mütéti terület többszöri kis mennyiségü öblítése javasolt. A gastroscopos randevú technikai alkalmazása olyan esetekben ajánlható, amikor az elváltozás helye biztonsággal nem azonosítható (különösen kisebb méretü tumorok esetén). Mind a laesio helyének megfelelő nyálkahártya-defektus, mind a gastrotomiás nyílások zárására monofil varróanyag alkalmazását javasoljuk.

A felső tápcsatornai ERAS protokoll alkalmazásával a beteg felépülése és exmissiója jelentősen felgyorsítható. Esetünkben nem várt komplikációként színezte a képet a beteg COVID-19-fertőzése és feltehetően a köhögés kapcsán fellépő vongálódás miatt kialakult haematemezis. Invazív vizsgálat és beavatkozás vagy transzfúzió nem vált szükségessé, eseménytelen megfigyelést követően tudtuk otthonába bocsátani.

Összefoglalásként elmondható, hogy a gastro-oesophagealis junctio közeli subepitheliális tumorok laparoszkópos 
transgastricus resectiója az általunk végzett technikával biztonságosan, a standard laparoszkópos mütéteknél megszokott müszerekkel, ballonnal ellátott portok segítségével hatékonyan kivitelezhetö.

\section{Irodalomjegyzék}

${ }^{1}$ Polkowski M: Endoscopic ultrasound and endoscopic ultrasound-guided fine-needle biopsy for the diagnosis of malignant submucosal tumors. Endoscopy. 2005; 37(7): 635-645.

${ }^{2}$ Dumonceau JM, Deprez PH, Jenssen C, Iglesias-Garcia $J$, Larghi A, Vanbiervliet $G$ : Indications, results, and clinical impact of endoscopic ultrasound (EUS)-guided sampling in gastroenterology: European Society of Gastrointestinal Endoscopy (ESGE) Clinical Guideline - Updated January 2017. Endoscopy. 2017; 49(7): 695-714.

${ }^{3}$ Ohashi S: Laparoscopic intraluminal (intragastric) surgery for early gastric cancer. A new concept in laparoscopic surgery. Surg Endosc. 1995; 9(2): 169-171.

${ }^{4}$ Geis WP, Baxt R, Kim HC: Benign gastric tumors. Minimally invasive approach. Surg Endosc. 1996; 10(4): 407-410.

${ }^{5}$ Tagaya N, Mikami H, Kogure H, Kubota K, Hosoya $Y$, Nagai $H$ : Laparoscopic intragastric stapled resection of gastric submucosal tumors located near the esophagogastric junction. Surg Endosc. 2002; 16(1): 177-179.
${ }^{6}$ Tagaya N, Mikami H, Kubota K: Laparoscopic resection of gastrointestinal mesenchymal tumors located in the upper stomach. Surg Endosc. 2004; 18(10): 1469-1474.

${ }^{7}$ Dulucq JL, Wintringer P, Mahajna A: Totally laparoscopic trans-hiatal gastroesophagectomy for benign diseases of the esophago-gastric junction. World J Gastroenterol. 2007; 13(2): 285-288.

${ }^{8}$ Uyama I, Ogiwara H, Takahara T, Kikuchi K, Iida S: Laparoscopic and minilaparotomy proximal gastrectomy and esophagogastrostomy: technique and case report. Surg Laparosc Endosc. 1995; 5(6): 487-491.

${ }^{9}$ Choi YB, Oh ST: Laparoscopy in the management of gastric submucosal tumors. Surg Endosc. 2000; 14(8): 741-745.

${ }^{10}$ Wiech T, Walch A, Werner M: Histopathological classification of nonneoplastic and neoplastic gastrointestinal submucosal lesions. Endoscopy. 2005; 37(7): 630-634.

${ }^{11}$ Xu X, Chen K, Zhou W, Zhang R, Wang J, Wu D: Laparoscopic transgastric resection of gastric submucosal tumors located near the esophagogastric junction. J Gastrointest Surg. 2013; 17(9): 1570-1575.

${ }^{12}$ Lee JH, Han HS, Kim YW, Min SK, Lee HK: Laparoscopic wedge resection with handsewn closure for gastroduodenal tumors. J Laparoendosc Adv Surg Tech A. 2003; 13(6): 349-353.

A cikk a Creative Commons Attribution 4.0 International License (https://creativecommons.org/licenses/by/4.0/) feltételei szerint publikált Open Access közlemény, melynek szellemében a cikk bármilyen médiumban szabadon felhasználható, megosztható és újraközölhetö, feltéve, hogy az eredeti szerző és a közlés helye, illetve a CC License linkje és az esetlegesen végrehajtott módosítások feltüntetésre kerülnek. (SID_1) 